\title{
Medication safety issues in the emergency department
}

\author{
Suheil Andreas Salamon ${ }^{*}$, Charlotte Arp Sørensen ${ }^{\dagger}$, Tina Birkeskov Axelsen \\ From 4th Danish Emergency Medicine Conference \\ Roskilde, Denmark. 25-26 November 2011
}

\section{Background}

The effect of clinical pharmacist conducted medication history, registration in electronic module and reconciliation, was studied in unscheduled patients admitted to our emergency department.

\section{Methods}

A prospective study which enrolled unscheduled patients presenting to a regional emergency department. In the control group, medication history, registration and reconciliation was conducted by junior doctors. Duration for medical journal record and medication registration was noticed separately. In the intervention group, clinical pharmacists conducted medication history, registration and reconciliation. Junior doctors conducted only medical journal record. Time was noticed for both groups.

\section{Results}

135 consecutive patients were enrolled: 44 patients in the control group and 91 patients in the intervention group. In the intervention group, there was a significant reduction of at least 15 minutes $(\mathrm{p}=0.005548)$, when junior doctors only conducted medical journal record, without medication history, registration and reconciliation. Clinical pharmacists used 38.5 minutes (CI $95 \%$ : $34.5-42.5)$, for conduction of medication history, registration and reconciliation.

\section{Conclusion}

32 unscheduled patients are admitted to our emergency department daily. We conclude that, an average of approximately 8 hours will be added to junior doctor's real time patient contact and treatment. The quality of

\footnotetext{
* Correspondence: salamon@dadlnet.dk

† Contributed equally

Regionshospitalet Randers, Skovlyvej 1, 8900 Randers, Denmark
}

medication history, registration and reconciliation, is also improved, when conducted by a clinical pharmacist.

Published: 16 April 2012

doi:10.1186/1757-7241-20-S2-P31

Cite this article as: Salamon et al: Medication safety issues in the emergency department. Scandinavian Journal of Trauma, Resuscitation and Emergency Medicine 2012 20(Suppl 2):P31.
Submit your next manuscript to BioMed Central and take full advantage of:

- Convenient online submission

- Thorough peer review

- No space constraints or color figure charges

- Immediate publication on acceptance

- Inclusion in PubMed, CAS, Scopus and Google Scholar

- Research which is freely available for redistribution

Submit your manuscript at www.biomedcentral.com/submit
C Biomed Central

\section{Biomed Central}

